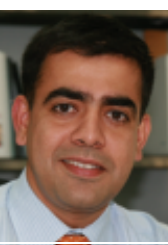

Amit Chanan

General Manager, Strategic Assets,

State Water Corporation, Parramatta Australia

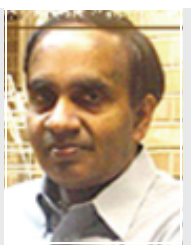

Vigneswaran Saravanamuth Pigneswaran Saravinth Profering and Technolion, University of Technology, Sydney, Broadway, Australia

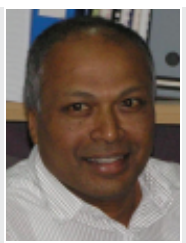
Senior Lecturer, Faculty of Engineering of Technology, Sydney, Broadway. Australia

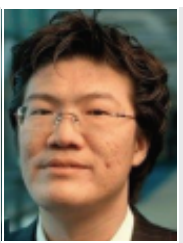

Lecturer, Faculty of Engineering and nformation Technology, University of Technology, Sydney, Broadway, Australia

\title{
Chemical-assisted physico-biological water mining system
}

A. Chanan MEng, MEM, MSc, V. Saravanamuth PhD, J. Kandasamy PhD and H. K. Shon PhD

Water mining is the process of extracting valuable water from a sewerage network by treating raw sewage to high standards. A range of commercially viable water mining treatment technologies are now available to treat sewage to specified water quality targets. Most of these technologies have minimal plant footprint requirements, making them suitable for decentralised operations. This paper discusses a hybrid water mining system that includes chemically assisted fine solids separation followed by a biological treatment process. Results from the first proof testing of this water mining system in Sydney, Australia are presented. The results confirm the suitability of the hybrid system for producing high-quality water for non-potable reuse.

\section{WATER MINING: AN INTRODUCTION}

The Australian Capital Territory Electricity and Water Company (ACTEW) coined the term water mining to describe the process of extracting raw sewage from a sewer and treating it to suitable standards for use as irrigation water for public open space. However, water mining can not only provide on-site recycled water for irrigation of public space, it can also be used for industrial or other uses (Chanan, 2009). The term water mining thus describes the process of extracting valuable water from a sewerage network, by treating raw sewage to very high standards. It is a relatively new term that is often used interchangeably with sewer mining. However, given that the substance of value being mined in this process is water and not sewerage, describing it as sewer mining is rather ambiguous and carries a negative connotation (Chanan and Kandasamy, 2009).

Figure 1 shows a typical set-up of a water mining scheme. Water mining operates independently of conventional centralised sewage treatment facilities. A small-scale treatment plant simply taps into a sewer main, extracts the sewage and processes it to a suitable standard. Sludge or any other process residues (such as filter backwash water and plant wash-down water) are returned to the sewer and treated in the usual manner at the central sewage treatment plant (Phillips, 2004).

In the USA, decentralised water supply systems such as water mining operations are commonly described as satellite treatment systems, referring to their outpost location away from central sewage treatment plants. The location of water mining facilities closer to the point of water use has also been

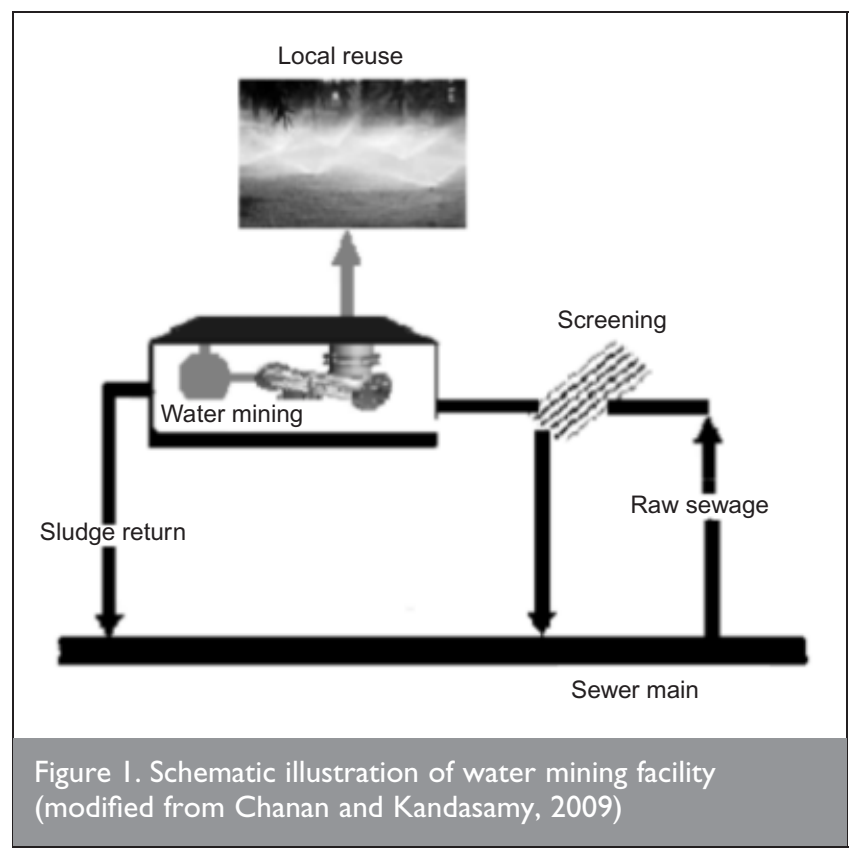

highlighted in the literature, with such schemes being called point-of-sale reuse (Rimer et al., 2004).

\section{MATERIALS AND METHODS}

Water treatment processes typically involve

(a) physical removal treatment technologies that rely on physical separation processes such as filtration, sedimentation and flotation to remove pollutants

(b) chemical removal processes in which chemicals, typically coagulants and flocculants, are used to increase the removal rate of pollutants

(c) biological removal technologies that use biological processes to transform pollutants to more manageable forms for separation.

A range of commercially viable treatment technologies are now available to treat sewage to the specified water quality targets. Given the emphasis on decentralised systems, most of these technologies have minimal plant footprint requirements, making them suitable for water mining operations.

Commercially available water mining technologies can be summarised into three major types (Landcom, 2006) 
(a) biological processes

(i) sequencing batch reactors

(ii) natural systems such as subsurface wetlands

(iii) rotating biological contractors

(b) physical processes

(i) sand and media filtration

(ii) membrane filtration (micro-, ultra-, nano-filtration and reverse osmosis)

(c) hybrid processes which combine physical, biological and/or chemical processes for optimum results

(i) fine solids separation (FSS) + biological process

(ii) membrane bio-reactors.

\section{CHEMICAL-ASSISTED PHYSICO-BIOLOGICAL HYBRID SYSTEM}

The majority of pollutants in domestic sewage are associated with fine particles $(<50 \mu \mathrm{m})$ and colloidal solids (Levine et al., 1985). A compact and cost-effective primary treatment process that can rapidly remove high levels of these fine and colloidal solids thus has obvious application in wastewater treatment and reuse. To be suitable for water mining facilities, such processes should be compact and low in capital cost. At the same time, it is also desirable that the process should be rapid and able to achieve good removal of solids and associated pollutants (Heist and Davey, 2002). The chemical-assisted physico-biological hybrid system discussed in this paper includes a primary treatment step of chemically assisted FSS, which meets the above criteria.

The hybrid system was originally developed by CDS Technologies (later Copa Water) and was marketed as ReAqua Hybrid System for water mining operations. This paper describes the performance of the first pilot test of this proprietary system in Sydney, Australia.

As illustrated in Figure 2, the hybrid system combines chemical, physical and biological treatment mechanisms. The system involves following four key treatment steps

(a) chemical-assisted FSS (chemical/physical) which uses coagulation to remove fine solids (b) submerged aerated filter (biological) which enables biodegradable organic and nutrient removal

(c) fine sand or multimedia filter (physical) which gives additional suspended solids removal

(d) ultraviolet (UV) disinfection, the last step in the treatment process, which is commonly coupled with chlorination to meet the residual chlorine requirements.

\section{I. Chemical-assisted FSS}

Chemical-assisted FSS uses a high-rate vortex screening technology to trap solids from the flow. The use of a hydrodynamic vortex separator allows much higher separation rates than can be achieved by other traditional processes, which are often limited by settling or floatation velocities (Heist and Davey, 2002).

The type of hydrodynamic vortex separator used in this system assists the effectiveness of the FSS process. Continuous deflective separation (CDS) vortex separators use expanded metal screens that have their raised surface in the direction of the flow. The raised surface deflects the boundary layer flowing along the screen away from the screen, giving the solids in the flow additional momentum that carries them away from the screen (Heist and Davey, 2002). This hydraulic design makes the screening process non-blocking and therefore the treatment rate is not reduced by increasing head loss across the screen as the screen becomes blocked. The tangential flow of liquid across the screen sweeps solids off the surface of the screen. This differs from the usual application of screens as sieves in which the liquid stream is forced directly onto the screen. The obvious benefit of this approach is that the solids are prevented from blocking the screen. Furthermore, solids much finer than the screen may also be captured as they are swept past the apertures (Heist and Davey, 2002).

Hydrodynamic vortex screening itself is not suitable for the removal of fine neutral-density solids less than $75 \mu \mathrm{m}$ in diameter (Heist and Davey, 2002). However, flocculation of the fine solids results in aggregates large enough to be captured in a vortex screening unit. The combination of flocculation and vortex separation therefore produces a clarification process that is not limited by settling or flotation velocities. The

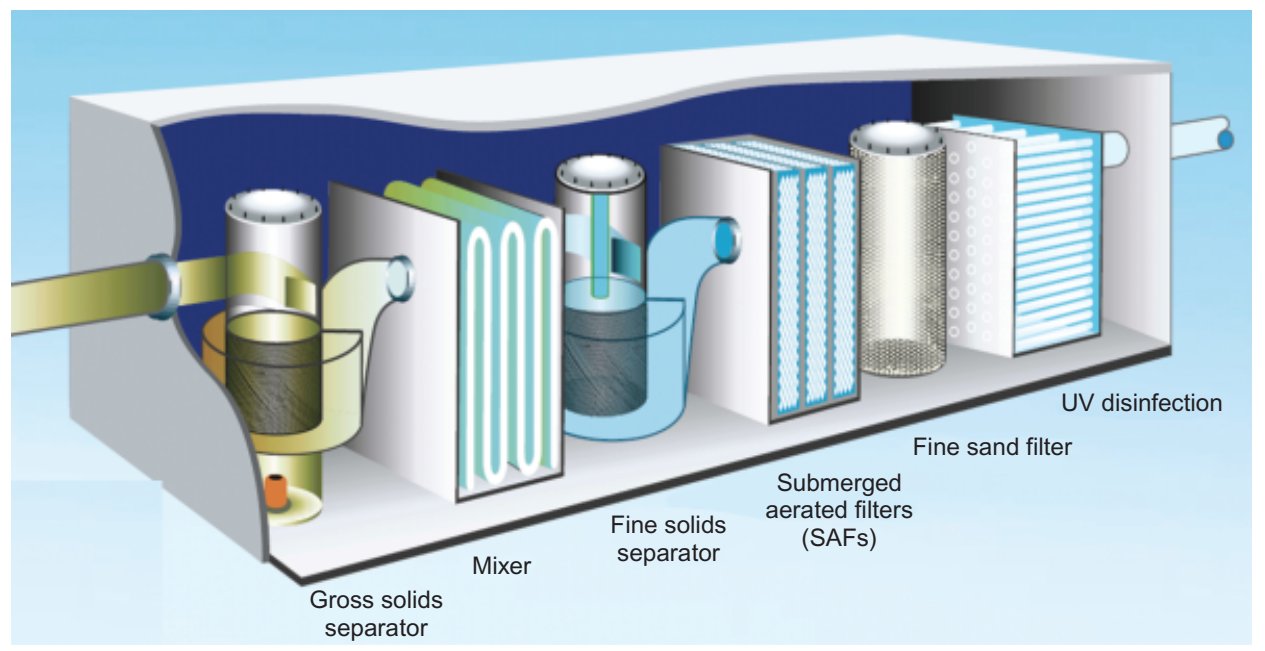


process has been demonstrated to achieve high levels of solids removal from raw sewage in a compact treatment process (Gray et al., 2000). Figure 3 schematically illustrates the process of chemical-assisted FSS, which consists of

(a) gross solids separation

(b) coagulant and polyelectrolyte addition

(c) mixing and maturation of flocs

(d) separation of flocs in a second vortex screening (FSS).

Significant effort was spent in developing the chemistry to produce flocs suitable for separation via a rapid screening process using a CDS-type vortex separator. The work aimed to develop flocs that were resistant to the mechanical shear forces that would be experienced on the screen of a CDS unit (Gray et al., 2000). Producing flocs that are both large and strong (i.e. resistant to mechanical shear) is challenging, since the ideal flocculation conditions for large flocs often tend to produce weak flocs (Heist and Davey, 2002). Increase in floc size as well as floc strength was achieved by increasing the polyelectrolyte dose. A cationic polyelectrolyte with high molecular weight and low to medium charge density was selected (Gray et al., 2000).

The effluent from this first step of the chemical-assisted physico-biological hybrid system is very clear in appearance. The two vortex separators - one to remove gross solids from the raw sewage and one to remove flocculated finer solids particularly enhances the effectiveness of the primary treatment step.

\subsection{Submerged aerated filter}

A submerged aerated filter (SAF) is defined as the biofilm system used for secondary and tertiary biological treatment of wastewater (Stensel and Reiber, 1983). A SAF consists of three phases (Figure 4)

(a) a solids phase that acts as the support media for microbial growth

(b) a liquid phase in which the solid material is submerged

(c) a gas phase created by the input of air into the reactor.

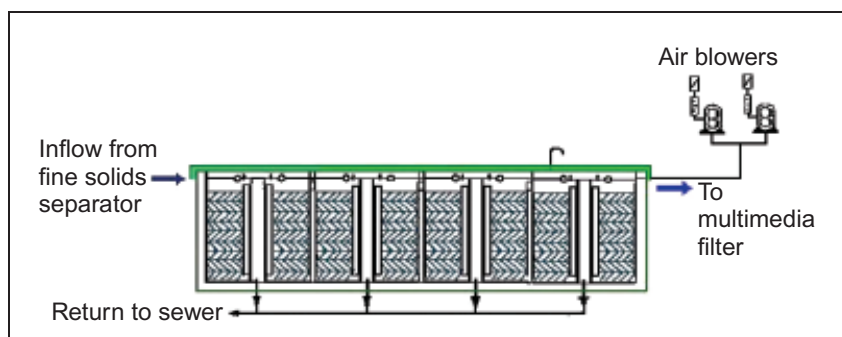

Figure 4. Biological treatment in submerged aerated filter

A SAF is typically effective in removing suspended solids, biochemical oxygen demand (BOD), ammoniacal nitrogen and total nitrogen. It is the second step in this hybrid water mining treatment system.

A SAF unit comprises a submerged bed of inert packing on which the micro-organisms responsible for treatment are attached. The effluent to be treated flows down through the packed bed and air is introduced near the base of the bed. As the treatment proceeds, the packed bed becomes blocked with the growth of micro-organisms and the capture of suspended solids, thus causing a resistance to the fluid flow (Mendoza-Espinosa and Stephenson, 1999). When this resistance to flow (or head loss) reaches a predetermined level or at a preset time, the filter must be washed. This is done using a combination of air (to scour the media) and water (to carry away surplus biomass and captured solids). The rate of head loss development and efficiency of filter washing are critical to the operation and performance of biological aerated flooded filters.

The volume of air required for treatment is a function of the pollution load, the endogenous respiration rate of the biomass and the oxygen transfer efficiency (Robinson et al., 1994). Adequate aeration is an essential element to reach the desired level of treatment (Vedry et al., 1994). When the aeration rate is too low, insufficient substrate removal will occur and anoxic zones may be created within the reactor. On the other hand, if the aeration rate is too high, scouring of the biofilm and reduction of solids removal efficiency may occur (Pearce, 1996).

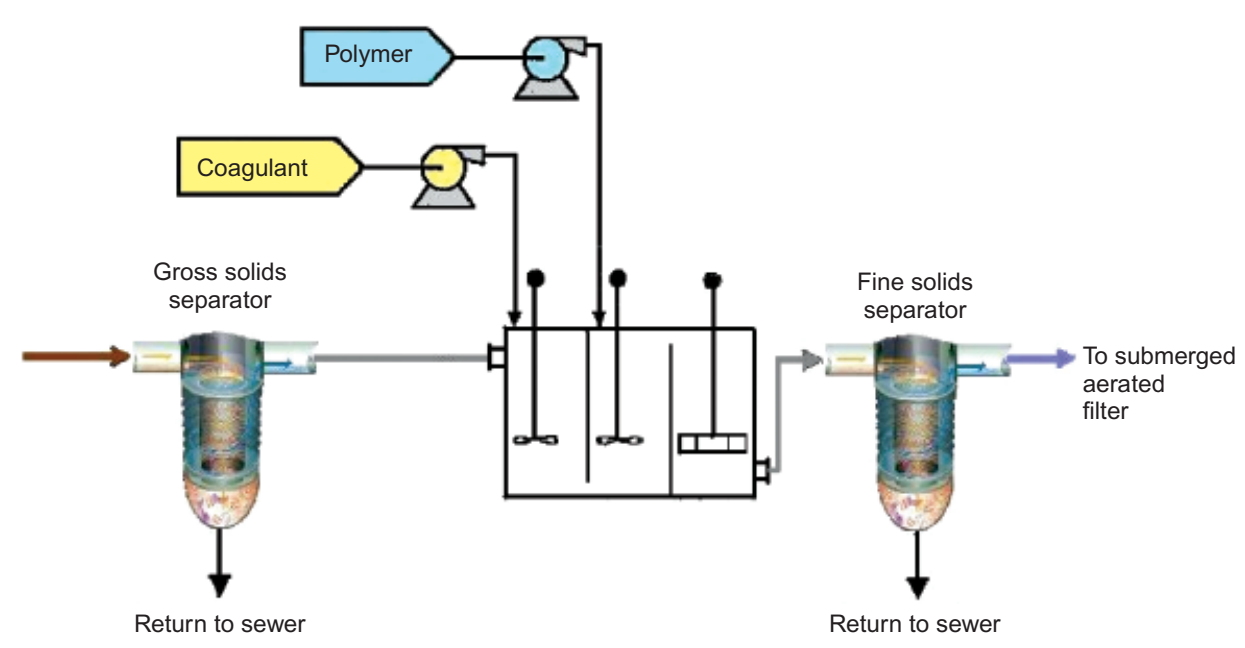

Figure 3. Chemical-assisted fine solids separation as pre-screening for biological treatment 
The SAF process results in significant biodegradable organic and nutrient removal from the effluent. This high-quality effluent is further polished in the third step of this hybrid system, involving fine sand filtration.

\subsection{Fine sand filtration}

Sand filter systems provide an additional layer of treatment to ensure that the product water is low in suspended solids. The filtration process involves passing water effluent through a filter medium to strain out colloidal particles such as earth particles, fine sand, anthracite, etc. Sand is the usual filter medium because of its low cost, durability and availability; it also has a relatively fine grain size (effective size $0 \cdot 15-0 \cdot 3 \mathrm{~mm}$ ) and a uniformity coefficient of less than 3 (Visscher, 1990).

Backwash of the sand is the most important process parameter for this type of water treatment. Sand is taken from the bottom of the bed and is pumped by an airlift into a washing chamber. From there it falls back onto the top of the sand bed. The quality of the filtered water depends on the grain size of the sand and on the backwash regime.

\subsection{Ultraviolet disinfection}

After sand filtration, the product water is passed through a UV disinfection system to ensure the removal of any diseasecausing micro-organisms (Figure 5). The UV disinfection system transfers electromagnetic energy from a mercury arc lamp to a micro-organism's genetic material (DNA and RNA). When UV radiation penetrates the cell wall of a microorganism, it penetrates the genetic material and retards its ability to reproduce (Clancy and Hargy, 2004). This damage prevents the micro-organism from multiplying or replicating in a human host; because the micro-organism cannot multiply, no infection can occur. UV disinfection requires a minimum applied dosage to be effective. This applied dosage is a function of the lamp intensity and exposure time, and these parameters are in turn directly affected by equipment configuration, flow path of water through the bank of lamps and the solids content of the water to be disinfected.

\section{RESULTS AND DISCUSSION}

For municipal water reuse involving unrestricted irrigation of open space, sports grounds and golf courses, Australian guidelines for water recycling recommend a log reduction target of 5 for enteric virus, 3.5 for enteric protozoa and 4 for

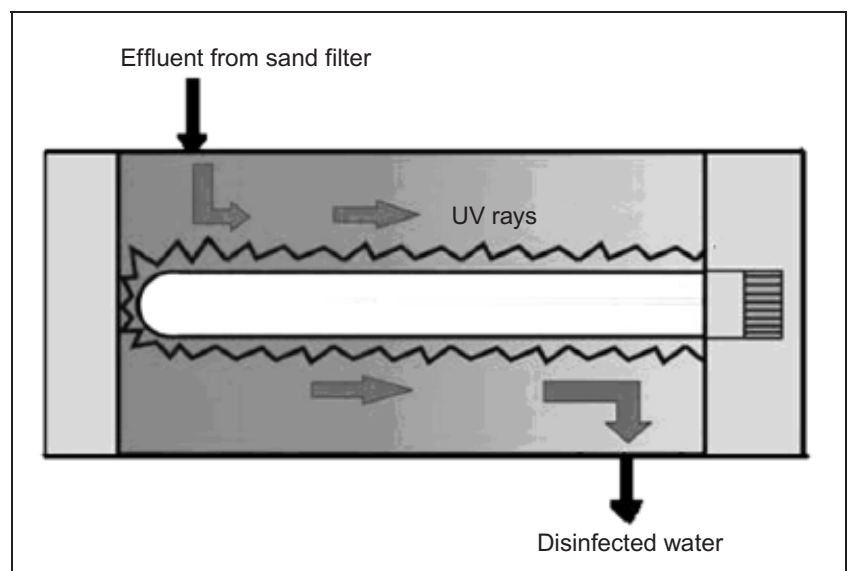

Figure 5. Ultraviolet disinfection of product water enteric bacteria (NWQMS, 2006). The guidelines recommend advanced treatment processes involving secondary treatment, membrane or physical filtration and disinfection. These guidelines do not specify water quality objectives for unrestricted municipal use, but instead suggest a site-specific case-by-case approach. However, the guidelines do specify $E$. coli levels of $<1$ per $100 \mathrm{ml}$.

Water mining schemes must follow suitable operation, monitoring and control regimes to ensure the desired standard of product water quality. In New South Wales, proponents of new water mining schemes have to undergo a proof testing/ validation phase. The aim of this phase is to ensure that appropriate treatment systems are selected and that the proposed treatment technologies/systems perform effectively. Once the delegated authorities approve a treatment technology's proof testing/validation process, it can then be recognised as a validated treatment system for use in recycled water systems for that particular influent quality and end use (DWE, 2008).

This chemical-assisted physico-biological hybrid system was the first water mining treatment technology to undergo proof testing in Sydney, Australia. The proof testing was conducted at the water recycling plant at Beverley Park golf course, and was jointly funded by Copa Water, Kogarah Municipal Council and Sydney Water Corporation. As stated above, the purpose of the proof-testing phase was to demonstrate the technology's ability to produce non-potable reuse water for municipal use in uncontrolled public areas.

Raw sewage for the pilot plant was sourced from the Ramsgate carrier main that traverses Beverley Park golf course. Being a predominantly residential catchment, the sewage quality (Table 1) was reflective of this land use. New South Wales Department of Energy Utilities and Sustainability (later renamed Department of Water and Energy) recommended a 4-week proof testing period and specified key parameters relevant to the proposed use of treated water. These are outlined in Table 2. Residual chlorine, turbidity, $\mathrm{pH}$ and salinity were monitored using a continuous online monitoring probe.

As is evident from results in Table 2, salinity was found to be a matter of concern. Further investigations into high salinity levels in the raw sewage and tide levels revealed a correlation due to infiltration of saline water from Kogarah Bay into the sewer carrier along the shore. The maximum salinity levels observed in the sewer main were over $9000 \mathrm{mg} / \mathrm{l}$, but there were daily 'windows' of low salinity of less than $400 \mathrm{mg} / \mathrm{l}$. The results indicated that low-salinity water was available in the sewer main with a lag time following low tide in Kogarah Bay (MHL, 2006). Product water with salinity levels between 415 and $830 \mathrm{mg} / \mathrm{l}$ is described as 'low' salinity water (Stevens et al., 2008); with the exception of some sensitive plants, most urban horticultural plants can be irrigated with such water.

Although not specified as a requirement during the proof testing phase, sampling was carried out during the final week of proof testing to measure nutrient levels in product water. Table 3 outlines the observed nutrient levels in the product water. In addition, $\mathrm{BOD}_{5}$ was also measured, although again 


\begin{tabular}{|c|c|c|c|c|}
\hline \multirow[t]{2}{*}{ Parameter } & \multicolumn{3}{|c|}{ Grab sample } & \multirow{2}{*}{$\begin{array}{c}12 \mathrm{~h} \\
\text { composite }\end{array}$} \\
\hline & I (7.00 am) & $2(9.00 \mathrm{am})$ & $3(9.00 \mathrm{pm})$ & \\
\hline Faecal coliform: CFU/I00 ml $\times 10^{6}$ & 18 & 14 & 25 & 49 \\
\hline $\mathrm{BOD}_{5}: \mathrm{mg} / \mathrm{l}$ & 220 & 200 & 220 & 210 \\
\hline Suspended solids: mg/l & 320 & 340 & 290 & 280 \\
\hline Turbidity: NTU & 110 & 640 & 130 & 110 \\
\hline Salinity: mg/l & 1340 & 4200 & 8970 & - \\
\hline $\mathrm{pH}$ & $8 \cdot 1$ & $8 \cdot 2$ & $7 \cdot 2$ & $7 \cdot 6$ \\
\hline Ammonia: mg/l & 44 & 43 & 26 & 36 \\
\hline TKN: mg/l & 68 & 47 & 34 & 55 \\
\hline Total nitrogen: mg/l & 68 & 66 & 44 & 65 \\
\hline Phosphorus: mg/l & $9 \cdot 5$ & $9 \cdot 8$ & $9 \cdot 6$ & 11 \\
\hline
\end{tabular}

\begin{tabular}{|c|c|c|c|c|c|}
\hline Parameter & Limit & $\begin{array}{l}\text { Week I } \\
\text { (9 Feb) }\end{array}$ & $\begin{array}{l}\text { Week } 2 \\
\text { (16 Feb) }\end{array}$ & $\begin{array}{l}\text { Week } 3 \\
\text { (23 Feb) }\end{array}$ & $\begin{array}{c}\text { Week } 4 \\
\text { (3 March) }\end{array}$ \\
\hline Faecal coliform: org/l00 ml & $<10$ & 0 & 0 & 0 & 0 \\
\hline Residual chlorine: $\mathrm{mg} / \mathrm{l}$ & I & $1 \cdot 27$ & 1.67 & $1 \cdot 2$ & 1.42 \\
\hline Turbidity: NTU & $<2$ & 0.92 & - & 0.98 & 1.63 \\
\hline Salinity: mg/l & $<500$ & 1750 & 9450 & 1010 & 9780 \\
\hline $\mathrm{pH}$ & - & 7.03 & 6.7 & 6.45 & $6 \cdot 37$ \\
\hline Bacteriophage: Pfu/ $100 \mathrm{ml}$ & - & 0 & 0 & 0 & 0 \\
\hline
\end{tabular}

\begin{tabular}{|lcccccc|}
\hline $\begin{array}{l}\text { Ammonia: } \\
\mathrm{mg} / \mathrm{l}\end{array}$ & Nitrite: $\mathrm{mg} / \mathrm{l}$ & $\begin{array}{c}\text { Nitrate: } \\
\mathrm{mg} / \mathrm{l}\end{array}$ & $\begin{array}{c}\text { Total Kjeldahl } \\
\text { nitrogen: } \\
\mathrm{mg} / \mathrm{l}\end{array}$ & $\begin{array}{c}\text { Total } \\
\text { nitrogen: } \\
\mathrm{mg} / \mathrm{l}\end{array}$ & $\begin{array}{c}\text { Ortho } \\
\text { phosphorus: } \\
\mathrm{mg} / \mathrm{l}\end{array}$ & $\begin{array}{c}\text { Total } \\
\text { phosphorus: } \\
\mathrm{mg} / \mathrm{l}\end{array}$ \\
\hline 3.5 & 23 & 4 & 27 & 0.71 & 0.83 \\
\hline Table 3. Observed nutrient levels in grab samples of product water in week 4 & \\
\hline
\end{tabular}

this was not a regulatory requirement for the proof testing of the water mining facility (Table 4).

\section{CONCLUSION}

The results of the proof testing phase confirmed that the product water from the chemical-assisted physico-biological hybrid system adequately met water quality requirements. Given that the water was to be used for irrigation of public open space, retention of some nutrients that aid vegetation growth was considered beneficial. Levels of nutrients and BOD observed did not pose any public health risks.

While not relevant for the proof testing phase itself, the investigations into salinity levels resulted in modifications to the final plant design. To maximise the window of low-salinity

\begin{tabular}{|lccc|}
\hline & Week I & Week 2 & Week 3 \\
\hline BOD $_{5}: \mathrm{mg} / \mathrm{l}$ & 4 & 4 & 3 \\
\hline $\begin{array}{l}\text { Table 4. Observed } \\
\text { water }\end{array}$ & & & \\
\hline
\end{tabular}

water available in the Ramsgate carrier, a balancing tank was introduced into the plant layout to store low-salinity primary treated effluent. The rapid treatment capacity of the chemically assisted FSS technology allowed the balancing tank to be placed after this primary treatment step. In the final plant, primary treated effluent from the balancing tank would be sourced for further biological and other remaining treatment steps.

\section{REFERENCES}

Chanan A (2009) Water mining. Elsevier SciTopics. See www.scitopics.com/Water_Mining.html for further details (accessed 09/10/2009).

Chanan A and Kandasamy J (2009) Water mining: planning and implementation issues for a successful project. In Waste Water Treatment Technologies, Encyclopedia of Life Support Systems (Vigneswaran S (ed.)). Unesco Publishing, UNESCOEOLSS Joint Secretariat, Paris, vol 11, pp. 258.

Clancy JL and Hargy TM (2004) UV inactivation of microorganisms in water - a review. Water Journal 31(1): 19-21.

DWE (Department of Water and Energy) (2008) Interim New South Wales Guidelines for Management of Private Recycled Water Schemes. DWE, Sydney. 
Gray SR, Becker NS, Booker NA et al. (2000) The role of organic polyelectrolytes in high rate alternatives to primary clarification. Proceedings of the 9th Gothenburg Symposium, Chemical Water and Wastewater Treatment - VI, Istanbul, Turkey. Springer, London, UK, 223-233.

Heist JA and Davey A (2002) A new high rate sewage clarification process. Proceedings of WEFTEC 2002 - The Water Quality Event, Chicago. Water Environment Federation, Virginia, USA, pp. 420-436.

Landcom (2006) Wastewater Reuse in the Urban Environment: Selection of Technologies (Holt P and James E (eds)). See www.landcom.com.au/downloads/uploaded/ Wastewater\%20reuse\%20technology\%20report_links2_ d960_de33.pdf for further details (accessed 28/08/2009).

Levine AD, Tchobanoglous G and Asano T (1985) Characterisation of the size distribution of contaminants in wastewater: treatment and reuse implications. Journal of Water Pollution 57(7): 805-816.

Mendoza-Espinosa L and Stephenson T (1999) A review of biological aerated filters (BAFs) for wastewater treatment. Environmental Engineering Science 16(3): 201-216.

MHL (Manly Hydraulics Laboratory) (2006) Beverley Park Sewer Flow and Water Quality Monitoring - Ramsgate Carrier. NSW Department of Commerce, Manly, New South Wales, Report MHL 1633.

NWQMS (National Water Quality Management Strategy) (2006) Australian Guidelines for Water Recycling: Managing Health and Environmental Risks (Phase 1). Natural Resource Management Ministerial Council, Environment Protection and Heritage Council and Australian Health Ministers Conference, Canberra.

Pearce P (1996) Aeration optimization of biological aerated filters. Proceedings of the 2nd Symposium on Biological Aerated Filters, Cranfield. Cranfield University, Bedford. Phillips S (2004) Is there gold in sewer mining? Waste Management \&t Environment. See www.wme.com.au/ categories/water/sept8_04.php for further details (accessed 28/08/2009).

Rimer A, Sandino J and Bosch R (2004) Point of sale solutions. Water Environment and Technology 16(1): 30-34.

Robinson AB, Brignal WJ and Smith AJ (1994) Construction and operation of a submerged aerated filter sewage treatment works. Journal of Water and Environmental Management 8(2): 215-227.

Stensel HD and Reiber S (1983) Industrial wastewater treatment with a new biological fixed-film system. Environmental Progress 2(2): 110-115.

Stevens DP, Smolenaars S and Kelly J (eds) (2008) Handbook for Irrigation of Amenity Horticulture with Recycled Water. Horticulture Australia Limited, Sydney.

Vedry B, Paffoni C, Gousailles M and Bernard C (1994) First months operation of two biofilter prototypes in the waste water plant of Acheres. Water Science \& Technology 29(10/ 11): $39-46$.

Visscher J (1990) Slow sand filtration: design, operation and maintenance. Journal of American Water Works Association 82(6): $67-71$.

\section{What do you think?}

To discuss this paper, please email up to 500 words to the editor at journals@ice.org.uk. Your contribution will be forwarded to the author(s) for a reply and, if considered appropriate by the editorial panel, will be published as discussion in a future issue of the journal.

Proceedings journals rely entirely on contributions sent in by civil engineering professionals, academics and students. Papers should be 2000-5000 words long (briefing papers should be 1000-2000 words long), with adequate illustrations and references. You can submit your paper online via www.icevirtuallibrary.com/content/journals, where you will also find detailed author guidelines. 